\title{
Det gode samarbeidet mellom kirken og skolen. Hvordan få det til?
}

Noen erfaringer

\author{
Av Svanhild Moen Refvik \\ SVAnHiLd Moen RefviK, født 1976, trosopplæringsleder for barn o-12 år \\ Svanhild.moen.refvik@frogn.kirken.no
}

Historisk sett har det alltid vært tette bånd mellom skolen og kirken. Også i Drøbak og Frogn, menigheten jeg jobber i. Men som i mange menigheter rundt omkring i landet, har kirke-skolesamarbeidet i vår kommune i mange år vært avgrenset til skolegudstjenester ved juletider, samt sporadiske kirkebes $\emptyset \mathrm{k}$ fra skoleklasser.

Ved innføringen av KRL-faget i 1997 og trosopplæringsreformen i 2003 understreket Stortinget forskjellen mellom skolens undervisning og kirkens trosopplæring. Skolen skulle stå for den brede kunnskapsformidlingen om alle religioner og livssyn til alle. Kirken på sin side skulle stå for trosopplæring for de døpte; en opplæring til en tro. Mange i kirken har vært usikker på samarbeidet med skolene etter dette, for et kirke-skolesamarbeid skal ikke være trosopplæring. Men også i nåtidige læreplaner er det lagt vekt på samarbeid i lokalsamfunnet, og i forarbeidene til KRL-faget var det lagt vekt på den kunnskapen alle elever kan få når skolen samarbeider med kirker og andre trossamfunn.

Det er store fordeler ved godt samarbeid mellom kirken og skolen, f.eks. at de som går på skole i dag, får del i den betydelige del av historie og kultur som er knyttet til kirken, en kompetanse som er verdifull uansett egen tro eller livssyn. Kirken og kirkens ansatte innehar dessuten mange ressurser og mye kunnskap og kompetanse som er unikt for kirken og som skolen med fordel kan få tilbud om og dra nytte av. Samarbeid gir også mulighet for variasjon i arbeidsmåtene for skoleelevene, f.eks. ved å bruke kirkerommet istedenfor klasserommet.

\section{Å etablere et SAMARbeid}

I Drøbak og Frogn startet vi våren 2012 arbeidet med å utvide vårt kirke-skolesamarbeid. Vi hadde allerede godt innarbeidede skolegudstjenester med gode 
rutiner og ryddighet i forbindelse med koordinering av dette. Men vi ønsket altså å utvide med mer samarbeid. Jeg kommer nå i de følgende avsnittene til å skissere det vi gjorde og det vi endte opp med.

\section{Utvalg i staben}

Vi satte ned et samarbeidsutvalg i staben som skulle arbeide ut et forslag til utvidet samarbeid med skolene. Trosopplærer, prester, ungdomsprest og musikere var med i dette utvalget. Vi gikk gjennom kompetansemålene i RLE-faget fra læreplanen både etter 4. årstrinn, 7. årstrinn og etter 10. årstrinn. Vi så også på andre fag, bl.a. musikk og kunst \& håndverk. Etter flere møter i dette utvalget endte vi opp med en skisse til en plan som vi ønsket å fremme for rektorene i kommunen.

\section{Rektorm $\phi$ te}

Vi tok kontakt med «preses» for rektorene og spurte om vi kunne komme på vårens siste rektorm øte, noe som ble gjennomført. Det var fem personer fra vår stab som møtte opp, godt forberedte. Der ble vår skisse til samarbeid presentert for rektorene, og rektorene fikk mulighet til å være kritiske, spørre og grave. De kom også med innspill til de forslagene vi hadde. Da kirkens tilmålte tid på møtet var over, kunne vi gå ut med en plan på utvidet samarbeid som kirken og skolen var sammen om, og som vi nå skulle sette i verk. Ved at rektorene gikk god for denne planen, fikk planen en «tyngde», og hver enkelt lærer måtte ikke ta stilling til om en eventuelt ville samarbeide med kirken. Rektorene hadde bestemt.

\section{Ansvar og tidspunkt}

Ved at vi nå hadde rektorenes godkjennelse til samarbeid var det bare for oss $\mathrm{i}$ staben å fordele ansvar og sette tidspunkt på året for de ulike «tiltakene». Vi tenkte at jo mer forutsigbart dette var for både oss og skolene, jo lettere var det å få til et godt samarbeid over tid.

\section{Driftsfase}

Planen vår har siden 2012 vært forutsigbar. Vi har gjennomført samarbeidet, og det har stort sett vært de samme ansatte som har stått for de samme tiltakene år etter år. Vi har også fătt jobbet sammen på tvers av yrkestitler. Tverrfagligheten har vært et faktum, noe som har beriket vår stab. Samarbeidstiltakene har sett slik ut:

- 2. trinn: Tema: «Påskevandring i Drøbak kirke» (vandring i kirkerommet der vi går gjennom de ulike dagene i påsken). Tidspunkt: Onsdag og torsdag i uken før påskeferien. Ansvar: Trosopplærer, sokneprest i Frogn, og kantor. 
- 4. trinn: Tema: «Drøbak kirkes innredning og symboler» (historie, kunst og arkitektur). Tidspunkt: Onsdag og torsdag i uke 38. Ansvar: Trosopplærer og sokneprest i Drøbak.

- 6. trinn: Tema: «Kirkemusikalske tradisjoner fra gregoriansk til gospel». Tidspunkt: Torsdag i uke 43. Ansvar: Kantor og menighetsmusiker.

- 8. trinn: Tema: «Kirkens plass $i$ storsamfunnet, samt livsritene; dåp, konfirmasjon, bryllup og begravelse». Tidspunkt: Onsdag og torsdag andre uken etter påske. Ansvar: Ungdomsprest, kapellan og kantor.

Det har også vært et samarbeid mellom kirken og den videregående skolen $\mathrm{i}$ kommunen, og det samarbeidet har vært et direkte samarbeid mellom ungdomspresten og religionslærerne. Tema har vært «Hellig rom og hellige handlinger».

\section{ERFARINGER}

Hvordan har det fungert og hvorfor? Hva har vi lært, hva har vist seg å være særlig viktig? Jeg vil i det følgende nå trekke fram noen momenter som jeg har erfart at er viktige ut fra vårt kirke-skolesamarbeid her i Drøbak og Frogn.

\section{Varsomhet}

Kirke-skolesamarbeid er noe helt annet enn et trosopplæringstiltak. Skolene må være helt trygge på at når de kommer med skoleklassene til kirken, så skal barna få undervisning og ikke forkynnelse. Kirkens ansatte som klarer å beherske denne grenseoppgangen, er med på å kvalitetssikre og trygge kirke-skolesamarbeidet. Det er bedre å være «føre var enn etter snar» $\mathrm{i}$ forholdet til skolene, for det kan fort skjære seg. Ett enkelt tilfelle av forkynnelse eller grenseoverskridelse i så henseende kan være nok til at kritiske foreldre eller lærere setter foten ned og samarbeidet kan skjære seg. Dette har vi hørt flere eksempler på fra ulike steder i landet, og vi har også hatt noen runder på dette i vår stab, for det er fort gjort å gå $\mathrm{i}$ «forkynnelses-fella». For noen år tilbake hadde vi en hendelse: En journalist fra lokalavisa var til stede på påskevandringen. Vi hadde kjøpt inn brød fra en lokal baker som vi brukte for å levendegjøre skjærtorsdagsfortellingen. Elevene fikk en liten smakebit mens vi snakket om måltidet som Jesus delte med disiplene. Dagen derpå var det en flott artikkel med mange bilder i avisa. Vi ansatte i kirken ble overrasket da journalisten hadde skrevet at «2. klasse ved NN skole deltok på nattverd i kirken». Hva skulle vi gjøre med dette? Vi valgte å skrive en e-post med en rettelse til avisa dagen etter der vi forklarte at det ikke var nattverd elevene fikk i kirken, men «brød for å konkretisere påskemåltidet». Videre skrev vi at «nattverd er en hellig handling som krever innstiftelsesord, noe som ikke ble gjennomført da elevene var på påskevandring». Hendelsen gjorde at vi etter dette valgte å droppe brød på påskevandringene, for når journalisten misforstod, da kan også foreldre og lærere misforstå. Vi har i ettertid valgt å ikke ta noen sjanser her. 


\section{Jevnlige rektorm $\phi$ ter}

Etter vårt første møte med rektorene i 2012 har vi hatt flere møtepunkter med dem, og funnet ut at noe av nøkkelen til vårt gode samarbeid, er nettopp dette: Jevnlige rektormøter. Her kan vi slå av en prat rundt bordet; kanskje med en sp $\varnothing \mathrm{k}$ og en kaffekopp. Her kan barrierer og fordommer brytes ned, og ikke minst; her kan rektorene komme med små og store tilbakemeldinger på kirkeskolesamarbeidet. Vi prøver, så langt det er mulig, å komme på et rektormøte annethvert år. Er det nye rektorer inne i bildet, er vår erfaring at det er viktig å komme på banen så fort som mulig. Hos oss har det vært et stabilt personale over mange år både i kirken og i rektorgruppen. Dette har helt klart vært en fordel.

\section{Kvalitet}

Det sier seg nærmest selv, men dersom skoleklasser kommer til kirken og skolene investerer tid i dette, så må kirkens ansatte også møte godt forberedte og med opplegg som skolen «tjener» på å delta på. Dersom oppleggene er pedagogisk dårlig lagt opp og med lite innhold eller variasjon, vil lærere spre rykter om dårlig opplegg, og samarbeidet kan ligge tynt an. Kirkestaber har mange fordeler i å ha kirkerom med flott kunst og arkitektur. I tillegg innehar mange ansatte mye kunnskap om kirke og kristendom, og musikerne som er ansatt $\mathrm{i}$ kirken, er profesjonelle. Alt dette er betydningsfull kompetanse som også skolene vil ha stor glede av å få del i. Så vi har forsøkt så godt vi har kunnet å være godt forberedte og laget flotte opplegg.

\section{Vær tidlig ute!}

Skolene er gode på å legge planer, det være seg både årsplaner, halvårsplaner, månedsplaner og ukeplaner. Dersom kirken skal få til et samarbeid, bør dette være forutsigbart for skolene. $\AA$ sende ut invitasjon til kirkebes $\varnothing \mathrm{k}$ uken før de skal møte opp, er som oftest dømt til å mislykkes. Vi har erfart at det er viktig å være ute i god tid. Før skolestart bør skolene ha mottatt datoplan for årets kirke-skolesamarbeid. Dernest har vi sendt ut egne invitasjoner før hvert samarbeidstiltak i tillegg, og dette har fungert for oss.

\section{Følge opp skolene}

For oss har det ofte vært nødvendig å følge opp skolene etter utsendt invitasjon. Vi har mange eksempler på at skolene ikke gir lyd fra seg. Da har hovedansvarlig ringt og purret. Kommer de eller kommer de ikke? Det har også hendt at det, tross tidlig utsendte datoplaner, ikke passer for skolene. Da har vi prøvd a komme skolene i møte og lagt til rette, så langt det har vært mulig. 


\section{Alle kommer!}

Kirke-skolesamarbeid er på mange måter enklere å håndtere enn trosopplæring. Vi sender en invitasjon til skolene, og alle elevene i en klasse kommer, sammen med sin lærer. Hos oss har det vært noen enkelttilfeller av fritak, og det har selvfølgelig vært helt i orden. Fritaksregelen gjelder også på kirke-skolesamarbeid. Men stort sett er dette begrenset til svært få elever.

\section{VEIEN VIDERE}

I Drøbak og Frogn menighet har vi hatt et utvidet kirke-skolesamarbeid i noen år nå. Vi har valgt å legge oss på samarbeidstiltak som går hvert andre år, altså på 2., 4., 6. og 8. skoleår samt 3. vgs. Vi har god erfaring med dette, men har også mye å gå på med tanke på utvidelse av dette samarbeidet. Hvorvidt vi kommer til å utvide ytterligere i årene som kommer, er foreløpig ikke bestemt. Vi har mange tanker og ideer om et større omfang i samarbeidet, men kanskje er det til det beste for både skolens og kirkens ansatte at samarbeidet holdes på et nokså nøkternt nivå. Det vil være lettere å prioritere samarbeidet på denne måten. Vi har erfart at å ha god kontakt med rektorgruppen og ha de med oss på laget hele veien, har vært avgjørende for et vellykket samarbeid. Dernest er kirke-skolesamarbeidet hos oss i vår stab noe det har vært snakket høyt om og ikke minst satset på over tid. Mange fra staben bidrar positivt inn i dette arbeidet og legger ned tid og krefter i dette. Vi har opplevd at kirke-skolesamarbeid er viktig for kirkens omdømme i lokalsamfunnet. Og er samarbeidet vellykket, da har begge parter glede og nytte av det.

\section{LITTERATUR}

Kristin Gunleiksrud og Yvonne Andersen. 2008. Samarbeid kirke-skole. Rammer og muligheter. Oslo: IKO-Forlaget

Kristin Gunleiksrud. 2009. Kirkebesøk, skolegudstjenester, høytidsvandringer. Oslo: IKOForlaget 